\title{
PHOSPHATE SOLUBILIZATION CAPACITY AND INDOLE ACETIC ACID PRODUCTION BY Trichoderma STRAINS FOR BIOMASS INCREASE ON BASIL AND MINT PLANTS
}

\author{
Lillian França Borges Chagas ${ }^{1}$, Aloisio Freitas Chagas Junior ${ }^{1} \&$ Henrique Guilhon de Castro ${ }^{1}$ \\ ${ }^{1}$ Universidade Federal do Tocantins. E-mail: lillianfbc@uft.edu.br, chagasjraf@uft.edu.br, hguilhon@uft.edu.br
}

\begin{abstract}
The use of microorganisms in medicinal plants may provide an increase in biomass. The objective of this work was to evaluate Trichoderma as a plant growth promoter, for the capacity of phosphate solubilization and synthesize of indole acetic acid (IAA) in vitro, and biomass production of two medicinal plants, basil and mint. Cultures were inoculated with two species of Trichoderma. The crop biomass as well as the relative efficiency were determined. Trichoderma species that solubilized phosphate and produced IAA, provided significant results in the accumulation of biomass of the crops, with relative efficiency of $276 \%$ for mint and $141 \%$ for basil, in relation to the control. The Trichoderma isolates showed phosphate solubilization capacity and IAA synthesis. Therefore, the studied crops presented biomass increase. These strains verified their capacity as plant growth promoters.
\end{abstract}

Keywords: Vegetables, biomass, Trichoderma harzianum, Trichoderma asperelloides

\section{CAPACIDADE DE SOLUBILIZAÇÃO DE FOSFATO E SÍNTESE DE AIA POR ESPÉCIES DE Trichoderma E INCREMENTO NA BIOMASSA DE PLANTAS DE MANJERICÃO E HORTELÃ}

\section{RESUMO}

$\mathrm{O}$ uso de microrganismos em plantas medicinais poderá proporcionar aumento em biomassa. $\mathrm{O}$ objetivo desse trabalho foi avaliar Trichoderma como promotor de crescimento vegetal, pela capacidade de solubilização de fosfato e síntese de AIA in vitro, e produção de biomassa de duas plantas medicinais, hortelã e manjericão. As culturas foram inoculadas com duas espécies de Trichoderma. Foi determinada a biomassa das culturas, bem como a eficiência relativa. As espécies de Trichoderma solubilizaram 
fosfato e produziram AIA, e proporcionaram resultados significativos no acúmulo de biomassa das culturas, com eficiência relativa de $276 \%$ para hortelã e $141 \%$ para o manjericão, em relação a testemunha. Os isolados de Trichoderma apresentaram capacidade de solubilização de fosfato e sintetizar AIA, e incremento da biomassa de plantas medicinais como observado para as culturas estudadas, demostrando a capacidade como promotoras de crescimento vegetal.

Palavras-chave: Hortaliças, biomassa, Trichoderma harzianum, Trichoderma asperelloides

\section{INTRODUCTION}

The influence of microorganisms on plant development includes the beneficial effects on seed germination, seedling emergence, grain growth, and yield. The use of microorganisms that promote the growth of plants and consequently the increase of agricultural production is one of the alternatives in the reduction of chemical fertilizers as well as environmental risks (MACHADO et al., 2012).

The use of these microorganisms in medicinal plants to improve biomass is a promising alternative, since the cultivation of these plants requires a more natural agriculture so that it does not interfere with the active principle.

Fungi of the genus Trichoderma are microorganisms that can promote increase in plant growth, positively influence seed germination, and assist in the development and yield of plants. This ability is related to the production of growth-promoting substances, phosphorus solubilization (OLIVEIRA et al., 2012; SILVA et al., 2012) and the synthesis of indole-acetic acid (GRAVEL et al. 2007; OLIVEIRA et al., 2012), as important agents for the production of plants. They also act in the control of diseases and they are inducers of resistance of several plants (CONTRERAS-CORNEJO et al., 2009; SANTOS et al., 2012; SILVA et al., 2012; ASUMING-BREMPONG, 2013; MACHADO et al., 2015).

Therefore, the objective of this work was to evaluate the efficiency of Trichoderma fungi, their capacity for solubilization of phosphate, synthesis of indole acetic acid (IAA) in vitro and its influence on the increase of the biomass of mint (Mentha spicata L.) and basil (Ocimum basilicum L.) in a greenhouse.

\section{MATERIALS AND METHODS}

The experiments were carried out in the Microbiology Laboratory and in a greenhouse at the experimental station of the Federal University of Tocantins (UFT), Gurupi campus, located in the 
southern region of Tocantins State (Brazil), latitude $11^{\circ} 43^{\prime} 45^{\prime \prime} \mathrm{S}$ and longitude $49^{\circ} 04^{\prime} 07^{\prime \prime} \mathrm{W}$, at $280 \mathrm{~m}$ altitude.

Two species of Trichoderma were used. T. asperelloides (UFT 201) and T. harzianum were identified through ITS (Internal Transcribed Spacer) region sequencing, at the Instituto Biológico, São Paulo. The GenBank access number and references are shown in Table 1.

Table 1. Trichoderma species identified through the ITS region sequencing, used in the experiments (São Paulo, SP, 2015).

\begin{tabular}{lccl}
\hline Trichoderma species & $\begin{array}{c}\text { GenBank } \\
\text { access }\end{array}$ & $\begin{array}{c}\text { Similarity index } \\
(\%)\end{array}$ & \multicolumn{1}{c}{ Reference } \\
\hline T. harzianum CIB T23 & EU279989 & 100 & Hoyos-Carvajal et al. (2009) \\
T. asperelloides GJS 04-217 & DQ381958 & 100 & Samuels et al. (2010) \\
\hline
\end{tabular}

The Trichoderma species were initially inoculated in PDA medium (potato dextrose agar) at $25 \pm$ $2^{\circ} \mathrm{C}$ for seven days to evaluate the phosphate solubilization capacity. Discs of approximately $8.0 \mathrm{~mm}$ in diameter were removed from these colonies, containing mycelium and spores, and transferred to Erlenmeyer $(250 \mathrm{~mL})$ in modified NBRIP media (NAUTIYAL, 1999) containing the following ingredients $\left(\mathrm{g} \mathrm{L}^{-1}\right)$ : 10.0 glucose, $5.0 \mathrm{MgCl}_{2} .6 \mathrm{H}_{2} \mathrm{O}, 0.25 \mathrm{MgSO}_{4} .7 \mathrm{H}_{2} \mathrm{O}, 0.2 \mathrm{KCl}, 0.1\left(\mathrm{NH}_{4}\right)_{2} \mathrm{SO}_{4} .50 \mathrm{~mL}$ $\mathrm{K}_{2} \mathrm{HPO}_{4}(10 \%)$, and $100 \mathrm{~mL} \mathrm{CaCl} 2$ (10\%) were added to medium for the formation of insoluble precipitate of calcium phosphate $\left(\mathrm{CaHPO}_{4}\right)$. The $\mathrm{pH}$ was adjusted to 7.0.

The quantitative estimate of phosphate solubilization was performed in three replicates in a completely randomized design. Incubation was performed at $25 \pm 2{ }^{\circ} \mathrm{C}$ on an orbital shaker at $150 \mathrm{rpm}$ for eight days. The concentration of soluble phosphorus $(\mathrm{P})$ was determined by the colorimetric method of Murphy \& Riley (1962), subtracting the soluble P contained in the treatments by the contained in the control sample (culture medium with phosphate and without inoculum). One part of the reagent was used for the assays, $0.5 \mathrm{ml}$ of the filtered sample plus $5 \mathrm{~mL}$ of distilled water for each sample. The reaction was carried out for 20 minutes. Then, the soluble $\mathrm{P}$ was quantified in a spectrophotometer at $725 \mathrm{~nm}$ wavelength. The standard curve for phosphorus $(\mathrm{P})$ quantification was made from monobasic potassium phosphate $\left(\mathrm{KH}_{2} \mathrm{PO}_{4}\right)$ and concentrations calculated in $\mu \mathrm{g} \mathrm{mL} \mathrm{L}^{-1}$.

The species were cultivated in PDA medium as in the evaluation of phosphate for the production of indole acetic acid in vitro for seven days. $8.0 \mathrm{~mm}$ diameter discs containing the mycelium and fungus spores were transferred to $250 \mathrm{~mL}$ Erlenmeyer flasks containing $50 \mathrm{~mL}$ of PD (potato and dextrose) 
medium in the absence (control) and presence of L-tryptophan. The concentration of L-tryptophan used was $100 \mathrm{mg} \mathrm{L}^{-1}$. Three replicates per treatment (isolates) were used in a completely randomized design.

The strains were grown under an orbital shaker $(150 \mathrm{rpm})$ at $26 \pm 2{ }^{\circ} \mathrm{C}$ for eight days. Then, the fungus mass was separated by centrifugation at 12,000 rpm for 15 minutes. A part of Salkowski's reagent $\left[\mathrm{FeCl}_{3} 0.5 \mathrm{~mol} \mathrm{~L}-1+\mathrm{HClO}_{4}(35 \%)\right]$ and two parts of the supernatant obtained from each isolate were used for the colorimetric analysis of indole-3-acetic acid (IAA) (GORDON \& WEBER, 1951). After the qualitative verification of the presence of IAA (pink color after 25 minutes of reaction at $28{ }^{\circ} \mathrm{C}$ in the dark), the phytormonium was quantified in a spectrophotometer at $530 \mathrm{~nm}$. Concentrations in $\mu \mathrm{gL}^{-1}$ were calculated from a standard curve with known concentrations of the synthetic form of the hormone ( 0 to $100 \mu \mathrm{g} \mathrm{mL}^{-1}$ ), which readings were the basis for calculating the concentration of IAA in the samples.

Twenty-four pots were used for the installation of greenhouse experiments. Twelve pots for each culture of mint (Mentha spicata L.) and basil (Ocimum basilicum L.). Commercial seeds treated with 0.15\% Captan (Captan 750) were used. The experiments were performed following the completely randomized design with three treatments and four replicates separately for each specie. The treatments were done with inoculation of $T$. asperelloides, T. harzianum (standard) and one control without inoculation.

The pots were filled with commercial substratum (Plantmax) and soil (sieved) classified as a dystrophic Yellow Red Latosol with a medium texture, in a ratio of 1:1. The soil was removed from a depth of 0-20 cm, obtained at the UFT Experimental Station, where the following characteristics were found: $4.0 \mathrm{cmol}_{\mathrm{c}} \mathrm{dm}^{-3} \mathrm{Ca}, 0.9 \mathrm{cmol}_{\mathrm{c}} \mathrm{dm}^{-3} \mathrm{Mg}, 0.1 \mathrm{cmol}_{\mathrm{c}} \mathrm{dm}^{-3} \mathrm{~K}, 2.8 \mathrm{mg} \mathrm{dm}^{-3} \mathrm{P}, 0.06 \mathrm{cmol}_{\mathrm{c}} \mathrm{dm}^{-3} \mathrm{Al}, 8.3$ $\mathrm{cmol}_{\mathrm{c}} \mathrm{dm}^{-3} \mathrm{CTC}, 5.0 \mathrm{cmol}_{\mathrm{c}} \mathrm{dm}^{-3}$ sum of bases (S), $61 \%$ base saturation (V), pH 5.8 in water, $1.7 \%$ organic matter, 79, 5.0, and $16 \%$ sand, silt and clay, respectively. $\mathrm{P}$ and $\mathrm{K}-$ Mehlich extractor $1, \mathrm{Al}^{3+}, \mathrm{Ca}^{2+}$ and $\mathrm{Mg}^{2+}-\mathrm{KCl}$ extractor (1 mol L-1) (EMBRAPA, 1997).

The Trichoderma species were grown separately in PDA petri plates and incubated at $25 \pm 2{ }^{\circ} \mathrm{C}$ with photoperiod of 12 hours for seven days for inoculants preparation (DIANESE et al. 2012). Six 5 mm diameter disks of each strain containing mycelia, spores and PDA medium were removed after growth. The strains were inoculated in polypropylene bags containing $300 \mathrm{~g}$ of commercial rice previously autoclaved at $121^{\circ} \mathrm{C}$ for 1 hour with $300 \mathrm{~mL}$ of distilled water. The bags were grown in a BOD incubator (Bio-Oxygen Demand) at $25 \pm 2{ }^{\circ} \mathrm{C}$ and photoperiod of 12 hours for seven days. Noninoculated (control) bags by Trichoderma were incubated only with autoclaved rice. Then, every two days the rice cooked and inoculated by Trichoderma was revolved to facilitate gas exchange, breakage 
of mycelial aggregates and increase of sporulation. After the seven days of incubation, $30 \mathrm{~g}$ of the colonized rice (inoculant) was removed for each $1.7 \mathrm{~L}$ pot filled with substrate and soil and colonized for 7 days for subsequent planting of the seeds of the different cultures. $30 \mathrm{~g}$ of the uncolonized rice was used for the control pots.

The concentration of Trichoderma used in the experiments was determined by quantification of the number of conidia. $1 \mathrm{~g}$ of colonized rice was washed in $10 \mathrm{ml}$ of sterilized water, followed by stirring for 1 min, and subsequent counting of the conidia in Neubauer chamber with the aid of an optical microscope. Mean concentrations of $1 \times 10^{9}$ conidia per gram of colonized rice were used.

Five seeds of mint and five of basil were sown in each pot. The thinning was carried out ten days after germination, leaving two plants per pot. After 35 days of planting (DAP), the plants were harvested. The following biomass evaluations were performed: root length (RL), number of leaves (NL), root dry mass (RDM), dry mass of the aerial part (DMAP), and total dry mass (TDM). The relative efficiency of each treatment was determined using the DMAP data and calculated according to the formula: Relative Efficiency $(\mathrm{RE})=($ DMAP inoculated by Trichoderma / DMAP without inoculant $) \times 100$.

The data were submitted to analysis of variance by the F test and the means of the treatments grouped by the Duncan test at $5 \%$ of significance using the statistical program Assistat.

\section{RESULTS AND DISCUSSION}

The results of phosphate solubilization capacity, $\mathrm{pH}$ and indole acetic acid synthesis by Trichoderma species are shown in Table 2.

Table 2. Mean values of calcium phosphate solubilization and indole acetic acid synthesis (IAA) in absence (AT) and presence (PT) of L-tryptophan by Trichoderma species (Gurupi, TO, 2015) ${ }^{1}$.

\begin{tabular}{lcccccc}
\hline \multicolumn{1}{c}{ Species } & \multicolumn{2}{c}{ calcium } & phosphate solubilization & \multicolumn{3}{c}{ IAA synthesis $\left(\mu \mathrm{g} \mathrm{mL}^{-1}\right)$} \\
& $\mu \mathrm{g} \mathrm{mL}^{-1}$ & $\%$ Solub. & $\mathrm{pH}$ & $\mathrm{AT}$ & $\mathrm{PT}$ & $\% \mathrm{IAA}^{3}$ \\
\hline T. asperelloides & $24.76 \mathrm{a}$ & 121.7 & 5.4 & $2.6 \mathrm{aB}$ & $3.9 \mathrm{aA}$ & 156 \\
T. harzianum & $20.34 \mathrm{~b}$ & 100 & 4.5 & $1.9 \mathrm{bB}$ & $2.5 \mathrm{bA}$ & 100 \\
Control & $0.44 \mathrm{c}$ & - & 6.1 & $0.2 \mathrm{cA}$ & $0.2 \mathrm{cA}$ & - \\
\hline CV $(\%)$ & 6.7 & - & - & 7.8 & 8.1 & - \\
\hline
\end{tabular}

Means followed by the same lowercase letter in the column and the same capital letter in the row do not differ by Duncan's test at $5 \%$ probability. ${ }^{2}$ Percentage of phosphate solubilization in relation to the standard T. harzianum. ${ }^{3}$ Percentage of IAA production of the isolates grown in the presence of L-Tryptophan in relation to the standard T. harzianum. CV-Coefficient of variation. 
T. asperelloides was significantly superior $(\mathrm{p}<0.05)$ to $T$. harzianum (standard) for phosphate solubilization, with a mean percentage of solubilization higher than $20 \%$ (Table 2).

There was a reduction of $\mathrm{pH}$ in the culture media with Trichoderma asperelloides and T. harzianum in the liquid medium with calcium phosphate (Table 2). The ability of phosphate solubilization by microorganisms may be related to the acidification of the culture medium, due to the decrease of the $\mathrm{pH}$ by the release of organic acids in the medium. Reduction of $\mathrm{pH}$ in culture medium cultivated by several fungus species was also observed by Vassilev et al. (2006) with Aspergillus niger. However, Kapri \& Tewari (2010), in an experiment with Trichoderma spp., concluded that, although $\mathrm{pH}$ reduction for individual cultures occurs up to 48 hours and after acquisition of constancy, soluble phosphate concentrations continue to increase after $48 \mathrm{~h}$. This clearly suggests that $\mathrm{pH}$ drop is not the single factor for phosphate solubilization.

Although phosphate solubilization capacity is related to acid production or $\mathrm{pH}$ decrease by microorganisms, these factors do not always correlate with the amount of soluble phosphate produced (STAMFORD \& NAHAS, 2010). In addition to these factors, fungus growth should be considered as another important factor for phosphate solubilization (BARROSO et al., 2006).

On the other hand, the Trichoderma isolates used in this study were able to produce IAA in PD culture medium supplemented or not with L-tryptophan, being higher in the presence of the inducer (Table 2). T. asperelloides presented a significantly higher value ( $\mathrm{p}<0.05)$ than $T$. harzianum in the presence of the inducer.

The results of root length (RL), number of leaves (NL), root dry mass (RDM), dry mass of aerial part (DMAP), and total dry mass (TDM) of the mint and basil are presented in Table 3.

Significantly higher values $(\mathrm{p}<0.05)$ in treatments with Trichoderma inoculation than in control were observed in all traits analyzed for the efficiency of inoculation of the strains in the substrate for growth of mint (Table 3). Higher values $(\mathrm{p}<0.05)$ for treatments with inoculation of Trichoderma species only for RDM, DMAP and TDM, compared to control were observed for basil. These results verified the positive effects of Trichoderma inoculation on growth and induction of resistance to diseases in vegetables, such as Silva et al. (2011) in cucumber plants, Benítez et al. (2004) in tomato, tobacco and cotton and Chacón et al. (2007) in tobacco and tomato. 
Table 3. Mean values of root length (RL), number of leaves (NL), root dry mass (RDM), dry mass of aerial part (DMAP), and total dry mass (TDM) of the mint and basil inoculated by Trichoderma ${ }^{1}$ and without inoculation (Gurupi, TO, 2015) ${ }^{1}$.

\begin{tabular}{lccccc}
\hline Treatments & RL & NL & RDM & DMAP & TDM \\
\hline T. asperelloides & $26.0 \mathrm{a}$ & $7.3 \mathrm{a}$ & $2.00 \mathrm{a}$ & $2.86 \mathrm{a}$ & $4.82 \mathrm{a}$ \\
T. harzianum & $24.5 \mathrm{a}$ & $6.9 \mathrm{a}$ & $1.95 \mathrm{a}$ & $2.66 \mathrm{a}$ & $4.61 \mathrm{a}$ \\
Control & $17.7 \mathrm{~b}$ & $4.0 \mathrm{~b}$ & $0.74 \mathrm{~b}$ & $0.76 \mathrm{~b}$ & $1.41 \mathrm{~b}$ \\
\hline CV $(\%)$ & 9.4 & 21.5 & 32.9 & 19.6 & 26.3 \\
\hline & & Basil & & $5.32 \mathrm{a}$ & $8.19 \mathrm{a}$ \\
\hline T. asperelloides & $30.0 \mathrm{a}$ & $26.8 \mathrm{a}$ & $2.87 \mathrm{a}$ & $5.22 \mathrm{a}$ & $8.02 \mathrm{a}$ \\
$T$. harzianum & $29.0 \mathrm{a}$ & $24.5 \mathrm{a}$ & $2.80 \mathrm{a}$ & $2.21 \mathrm{~b}$ & $3.45 \mathrm{~b}$ \\
Control & $29.5 \mathrm{a}$ & $21.3 \mathrm{a}$ & $1.24 \mathrm{~b}$ & 15.1 & 15.7 \\
\hline CV $(\%)$ & 9.0 & 14.5 & 23.7 & & \\
\hline
\end{tabular}

${ }^{1}$ Means followed by the same lowercase letter in the columns do not differ by Duncan test at $5 \%$ significance. CV (\%): Coefficient of Variation

Figure 1 presents the results of the relative efficiency of the two medicinal plants, which relates the DMAP of the treatments inoculated by Trichoderma in relation to the control without inoculation. A significant difference $(\mathrm{p}<0.01)$ between treatments was observed. The relative efficiency was higher for treatments with inoculation of Trichoderma species for both cultures. The cultures showed an increase in mean above $250 \%$ for mint and $140 \%$ for basil compared to the control (Figure 1).

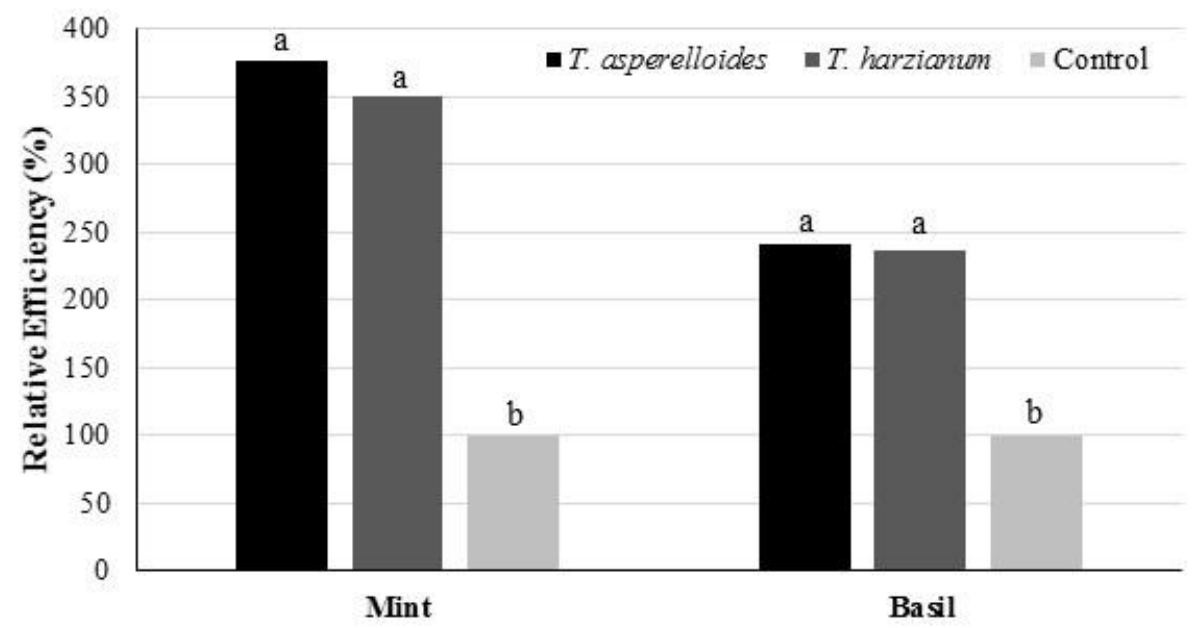

Figure 1. Relative efficiency in Trichoderma-inoculated mint and basil cultures. Means followed by the same lowercase letter do not differ by Duncan test at 5\% significance (Gurupi, TO, 2015).

The production of auxins is one of the mechanisms most frequently presented to explain the effects of Trichoderma on plant growth (CONTRERAS-CORNEJO et al., 2009, 2016). Recent studies demonstrate that in the early stages of the Trichoderma-plant interaction, metabolites such as auxins and 
protein compounds released by Trichoderma are perceived by the roots, altering multiple hormonal mechanisms that control the growth and development of the plant under normal or stress conditions (BAE et al., 2011; GARNICA-VERGARA et al., 2015; CONTRERAS-CORNEJO et al. 2016). As a result of the colonization of the root system by Trichoderma, it could be the protection in the rhizosphere against phytopathogens, as well as a more developed root system, favoring the absorption of nutrients and water (CONTRERAS-CORNEJO et al. 2013, 2015, 2016).

Several authors also suggest the ability to increase plant growth and productivity by Trichoderma species by the ability to solubilize mineral nutrients (HARMAN et al., 2004, SILVA et al., 2012; CHAGAS et al., 2015; CONTRERAS-CORNEJO et al., 2016).

The increase in biomass and the promotion of plant growth by the fungus efficiency of the genus Trichoderma, as can be observed in this work, have already been reported by several other researchers in the corn (RESENDE, 2004), tomato (GRAVEL et al. 2007), cucumber (SILVA et al., 2011), cowpea (OLIVEIRA et al., 2012), and rice (ASUMING-BREMPONG, 2013, CHAGAS et al., 2015).

This work demonstrates the potential of Trichoderma as a plant growth promoter, which may be related to phosphate solubilization capacity and indole acetic acid (IAA) synthesis.

\section{CONCLUSIONS}

The species of Trichoderma asperelloides (UFT 201) and T. harzianum presented phosphate solubilization capacity and synthesized IAA.

The inoculation of these Trichoderma species provided an increase in the biomass of the mint and basil cultures.

\section{REFERENCES}

ASUMING-BREMPONG, S. 2013. Phosphate solubilizing microorganisms and their ability to influence yield of rice. Agricultural Science Research Journal, Riade, v.3, n.12, p.379-386.

BAE, H.; ROBERTS, D.P.; LIM, H.S.; STREM, M.D.; PARK, S.C.; RYU, C.M.; MELNICK, R.L.; BAILEY, B.A. 2011. Endophytic Trichoderma isolates from tropical environments delay disease onset and induce resistance against Phytophthora capsici in hot pepper using multiple mechanisms. Mol. Plant Microbe Interact, Virginia, v.24, n.5, p.336-51.

BARROSO, C.B.; PEREIRA, T.G.; NAHAS, E. 2013. Solubilization of $\mathrm{CaHPO}_{4}$ and AlPO 4 by Aspergillus niger in culture media with diferente carbono and nitrogen sources. Brazilian Journal Microbiology, São Paulo, v.37, p.434-438.

BENÍTEZ, T.; RINCÓN, A.M.; LIMÓN, M.C.; CODÓN, A.C. 2004. Biocontrol mechanisms of Trichoderma Strains. International Microbiology, Barcelona, v.7, p.249-260. 
CHACÓN, M.R.; RODRÍQUEZ-GALÁN, O.; BENÍTEZ, T.; SOUSA, S.; REY, M.; LLOBELL, A.; DELGADO-JARANA, J. 2007. Microscopic and transcriptome analyses of early colonization of tomato roots by Trichoderma harzianum. International Microbiology, Barcelona, v.10, p.19-27.

CHAGAS, L.F.B.; CHAGAS JUNIOR, A.F.; CARVALHO, M.R. de; MILLER, L. de O.; COLONIA, B.S.O. 2015. Evaluation of the phosphate solubilization potencial of Trichoderma strains (Trichoplus JCO) and effects on rice biomass. Journal of Soil Science and Plant Nutrition, Temuco, v.15, n.3, p.794-804.

CONTRERAS-CORNEJO, H.A.; MACÍAS-RODRÍQUEZ, L.; CORTÉS-PENAGOS, C.; LÓPEZBUCIO, J. 2009. Trichoderma virens, a plant bene- ficial fungus, enhances biomass production and promotes lateral root growth through an auxin-dependent mechanism in Arabidopsis. Plant Physiology, Rockville, v.149, n.3, p.1579-1592.

CONTRERAS-CORNEJO, H.A.; ORTIZ-CASTRO, R.; LÓPEZ-BUCIO, J. 2013. Promotion of plant growth and the induction of systemic defense by Trichoderma: Physiology, genetics and gene expression. In: MUKHERJEE, P.K. (ed.). Trichoderma Biology and Applications. London: CABI, 2013, p.175-96.

CONTRERAS-CORNEJO, H.A.; LÓPEZ-BUCIO, J.S.; MÉNDEZ-BRAVO, A.; MACÍASRODRIGUÉZ, L.; RAMOS-VEGA, M.; GUEVARA-GARCÍA, A.A.; LÓPES-BUCIO, J. 2015. Mitogen-activated protein kinase 6 and ethylene and auxin signaling pathways are involved in Arabidopsis root-system architecture alterations by Trichoderma atroviride. Mol Plant Microbe Interact, Virginia, v.28, n.6, p.701-10.

CONTRERAS-CORNEJO, H.A.; MACÍAS-RODRÍQUEZ, L.; DEL-VAL, E.; LARSEN, J. 2009. Ecological functions of Trichoderma spp. and their secondary metabolites in the rhizosphere: interactions with plants. FEMS Microbiology Ecology, Oxford, v.92, p.1-17.

DIANESE, A. de C.; BLUM, L.E.B.; MELLO, S.C.M. de. 2012. Uso de Trichoderma spp. para o manejo da podridão-do-pé-do-mamoeiro causada por Phytophthora palmivora Butler. Planaltina-DF: Embrapa Cerrados, 18 p.

EMBRAPA (Empresa Brasileira de Pesquisa Agropecuária). 1997. Manual de métodos de análise de solos. 2. ed. Rio de Janeiro: Centro Nacional de Pesquisa de Solos. EMBRAPA - CNPS, 212 p.

GARNICA-VERGARA, A.A.; BARRERA-ORTIZ, S.; MUNÕZ-PARRA, E.; RAYA-GONZÁLES, J.; MÉNDEZ-BRAVO, A.; MACÍAS-RODRIGUEZ, L.; RUIZ-HERRERA, L.F.; LÓPES-BUCIO, J. 2015. The volatile 6-pentyl-2H-pyran-2-one from Trichoderma atroviride regulates Arabidopsis thaliana root morphogenesis via auxin signaling and ethylene insensitive 2 functioning. New Phytol, Lancaster, v.209, n.4, p.1496-1512.

GORDON, S.A.; WEBER, R.P. 1951. Colorimetric estimation of indole acetic acid. Plant Physiology, Rockville, v.26, n.1, p. 192-195.

GRAVEL, V.; ANTOUN, H.; TWEDDELL, R.J. 2007. Growth stimulation and fruit yield improvement of greenhouse tomato plants by inoculation with Pseudomonas putida or Trichoderma atroviride: Possible role of índole acetic acid (IAA). Soil Biology \& Biochemistry, Amsterdam, v.39, n.8, p.1968-1977.

HARMAN, G.E.; HOWELL, C.R.; VITERBO, A.; CHET, I.; LORITO, M. 2004. Trichoderma species opportunistic, avirulent plant symbionts. Nat Rev Microbiol, Nova York, v.2, n.1, p.43-56.

HOYOS-CARVAJAL, L.; ORDUZ, S.; BISSETT, J. 2009. Genetic and metabolic biodiversity of Trichoderma from Colombia and adjacent neotropic regions. Fungal Genetics and Biology, Madison, v.46, n.9, p.615-631.

KAPRI, A.; TEWARI, L. 2010. Phosphate solubilization potential and phosphatase activity of rhizospheric Trichoderma spp. Brazilian Journal of Microbiology, São Paulo, v.41, n.3, p.787-795. 
MACHADO, D.F.M.; PARZIANELLO, F.R.; SILVA, A.C.F. da; ANTONIOLLI, Z.I. 2012. Trichoderma no Brasil: O fungo e o bioagente. Revista de Ciências Agrárias, Lisboa, v.35, n.1, p.274-288.

MACHADO, D.F.M.; TAVARES, A.P.; LOPES, S.J.; SILVA, A.C.F. da. 2015. Trichoderma spp. na emergência e crescimento de mudas de cambará (Gochnatia polymorpha (Less.) Cabrera). Revista Árvore, Viçosa-MG, v.39, n.1, p.167-176.

MURPHY, J.; RILEY, J.P. 1962. A modified single solution method for determination of phosphate in natural waters. Analytical Chemistry Acta, Amsterdam, v.27, p.31-36.

NAUTIYAL, C.S. 1999. An efficient microbiological growth medium for screening phosphorus solubilizing microorganisms. FEMS Microbiology Letters, Malden, v.170, n.1, p.265-270.

OLIVEIRA, A.G.; CHAGAS JUNIOR, A.F.; SANTOS, G.R. dos; MILLER, L.O.; CHAGAS, L.F.B. 2012. Potencial de solubilização de fosfato e produção de AIA por Trichoderma spp. Revista Verde de Agroecologia e Desenvolvimento Sustentável, Pombal, v.7, n.3, p.149-155.

RESENDE, M. L. 2004. Inoculação de sementes de milho utilizando o Trichoderma harzianum como promotor de crescimento. Ciência e Agrotecnologia, Lavras, v.28, n.4, p.793-798.

SAMUELS, G.J.; ISMAIEL, A.; BON, M.C.; DE RESPINIS, S.; PETRINI, O. 2010. Trichoderma asperellum sensu lato consists of two cryptic species. Mycologia, Lawrence, v.102, n.4, p.944-966.

SANTOS, C.C.; OLIVEIRA, F.A. de; SANTOS; M.S. dos; TALAMINI; V.; FERREIRA; J.M.S.; SANTOS; F.J. dos. 2012. Influência de Trichoderma spp. sobre o crescimento micelial de Thielaviopsis paradoxa. Scientia Plena, Aracaju, v.8, n.4. p.1-5.

SILVA, V.N. da; GUZZO, S.D.; LUCON, C.M.M.; HARAKAVA, R. 2011. Promoção de crescimento e indução de resistência à antracnose por Trichoderma spp. em pepineiro. Pesquisa Agropecuária Brasileira, Brasília, v.46, n.12, p.1609-1618.

SILVA, J.C. da; TORRES, D.B.; LUSTOSA, D.C.; FILIPPI, M.C.C de; SILVA, G.B. da. 2012. Rice sheath blight biocontrol and growth promotion by Trichoderma isolates from the Amazon. Amazonian Journal of Agricultural and Environmental Sciences, Belém, v.55, n.4, p.243-250.

STAMFORD, N.P.; NAHAS, E. 2010. Microrganismos solubilizadores de minerais. In: FIGUEIREDO, M. V. B. et al. (Ed.). Biotecnologia aplicada à agricultura. Brasília, DF: Embrapa Informação Tecnológica; Recife, PE: Instituto Agronômico de Pernambuco (IPA), p. 561-581.

VASSILEV, N.; MEDINA, A.; AZCON, R.; VASSILEVA, M. 2006. Microbial solubilization of rock phosphate on media containing agro-industrial wastes and effect of the resulting products on plant growth and P uptake. Plant and Soil, Amsterdam, v.287, n.1-2, p.77-84. 